\title{
HUBUNGAN ANTARA MOTIVASI BELAJAR DENGAN PEMAHAMAN KONSEP FISIKA PESERTA DIDIK MAN BARAKA
}

\author{
Muhammad Amran Shidik
}

Fakultas Ilmu Pendidikan, Universitas Timor,

Jl. El Tari Km. 09 Kel. Sasi Kota Kefamenanu, Timor Tengah Utara

e-mail:muh.amranshidik@gmail.com,

\begin{tabular}{c|c|c|c}
\hline Diterima 20 Juli 2020 & Direvisi 3 Agustus 2020 & Disetujui 9 Agustus 2020 & Dipublikasikan 29 Agustus 2020 \\
\hline \multicolumn{4}{c}{ https://doi.org/10.33369/jkf.3.2.91-98 } \\
\hline
\end{tabular}

\begin{abstract}
ABSTRAK
Mengetahui hubungan antara motivasi belajar dengan pemahaman konsep fisika peserta didik MAN Baraka merupakan tujuan dilakukannya penelitian ini. Penelitian ini termasuk dalam penelitian korelasi produk momen, dimana ada dua variabel yang ingin dikatahui hubungan dan arah hubungannya, serta menggunakan pendekatan kuantitatif. Subjek dari penelitian ini adalah seluruh kelas X MIA MAN Baraka dengan total 121 orang peserta didik. Pengumpulan data menggunakan dua jenis instrument yakni instumen non-tes dan tes masing-masing untuk mengetahui motivasi belajar dengan jumlah 37 pernyataan, setiap pernyataan memiliki 5 pilihan jawaban dan pemahaman konsep fisika peserta didik dengan jumlah butir soal 26 yang setiap nomornya memiliki lima alternatif jawaban. Dengan menggunakan analisis korelasi produk momen diperoleh hasil penelitian yaitu nilai signifikansi 0,008<0,05 yang berarti Ho ditolak dan Ha diterima. Dari hasil penelitian ini dapat disimpulkan bahwa ada hubungan antara motivasi belajar dengan pemahaman konsep fisika peserta didik MAN Baraka dengan arah korelasinya adalah positif. Dengan ini, guru-guru ketika akan melakukan pembelajaran, baiknya memberikan motivasi terlebih dahulu kepada peserta didik agar mereka termotivasi. Ketika pererta didik sudah termotivasi, maka peserta didik akan bersemangat dan memungkinkan mereka untuk mudah dalam memahami konsep-konsep pelajaran sehingga akan memperoleh hasil belajar yang lebih baik.
\end{abstract}

Kata kunci: motivasi, belajar, pemahaman, konsep, fisika

\begin{abstract}
Knowing the relationship between learning motivation and understanding students' MAN Baraka concepts is the aim of this study. This research was included in product-moment research, where there were two variables that wanted to know the relationship and direction needed, and used quantitative research. The subjects of this study were all students of class X MIA MAN Baraka with a total of 121 students. Data collection used two types of instruments namely non-test and each test to determine learning motivation with a total of 37 answers, each of which had 5 answer choices and students' understanding of concepts with a total of 26 items, each of which had five alternative answers. By using product evaluation analysis when the results of significance $0.008<0.05$ which mean that Ho was rejected and Ha was accepted. From the results of this study, it can be concluded that there is a relationship between learning and learning with the understanding of MAN Baraka students' concepts and the direction of correlation is positive. With this, the teacher when going to learn, it is better to provide motivation in advance to students so that they are motivated. When students are motivated, students will be excited and allow them to easily understand the concepts of the lesson so that they will get better learning outcomes.
\end{abstract}

Keywords: motivation, learning, understanding, concepts, physics

\section{PENDAHULUAN}

Belajar sebagai kebutuhan pokok setiap manusia sebab selama hidup, manuisa akan terus belajar. Ketika belajar, tentunya apa yang dipelajari harus dipahami terutama konsep dari sebuah materi, seperti materi fisika. Dengan menguasai konsep pada materi tertentu maka, besar kemungkinan untuk memperoleh hasil yang baik pula. Penilaian untuk mendapatkan hasil belajar saat ini dibagi menjadi tiga bagian yaitu penilaian ranah kognitif, ranah afektif, dan ranah 
psikomotor. Hasil belajar dalam ranah kognitif atau biasa kita disebut dengan hasil belajar kognitif merupakan salah satu komponen untuk menilai kemampuan peserta didik dalam mempelajari materi tertentu. Ranah kognitif merupakan bagian dari kemampuan yang berhubungan dengan dimensidimensi pengetahuan, penalaran, atau pikiran (1).

Hasil belajar kognitif salah satu komponen penilaiannya adalah pemahaman. Pemahaman adalah derajat kemampuan yang diharapkan kepada siswa agar dapat memahami makna atau konsep, keadaan serta kenyataan yang diketahuinya (2). Dalam hal belajar fisika yang melekat dengan konsep serta apliksi dalam kehidupan sehari-hari, sangat penting untuk memahami konsepkonsep tertentu sebelum melakukan aplikasi dari teori yang telah dipelajari sebelumnya. Misalnya dalam konsep hukum Newton yang diaplikasikan dalam penggunaan katrol untuk memudahkan pekerjaan sehari-hari, konsep perubahan suhu dan masih banyak konsep lainnya. Untuk mengaplikasikan konsep-konsep tersebut dengan baik, maka diperlukan pemahaman konsep yang baik pula tentunya.

Kemampuan berpikir manusia yang menjadi dorongan di setiap satuan pendidikan dan univerisitas adalah pemahaman. Pemahaman termasuk sebagai proses pembelajaran dalam memperoleh tujuan suatu kegiatan belajar. Pemahaman menempati urutan yang sangat krusial dan strategis dalam kegiatan belajar, sebab menjadi rekonstruksi nilai dari beberapa hubungan, tidak hanya sebagai proses asimilasi dari pengetahuan yang sudah ada sebelumnya (3). Dalam hal ini, pemahaman yang dimaksud yaitu pemahaman konsep fisika peserta didik. Pemahaman konsep merupakan dasar dan tahapan penting dalam rangkaian pembelajaran matematika (4).

Pemahaman konsep adalah proses, perbuatan, cara memahami ide-ide materi pembelajaran, dimana peserta didik tidak sekedar mengenal dan mengetahui, tetapi mampu mengungkapkan kembali konsep yang lebih mudah dimengerti serta mampu mengaplikasikannya (5). Pemahaman konsep fisika merupakan kemampuan menerima arti-arti seperti mampu menjelaskan materi fisika yang dipelajari dan diarahkan kebentuk yang lebih dipahami oleh peserta didik sendiri dan menginterpretasikan makna dari penjelasan-penjelasan ketika proses belajar fisika yang terjadi sebagai hasil dari melakukan pengamatan.

Salah satu variabel yang mempengaruhi pemahaman konsep fisika peserta didik yakni motivasi belajar (6). Penelitian ini serupa dengan penelitian lainnya yang mengungkapkan bahwa motivasi mempengaruhi pemahaman konsep peserta didik (7). Kedudukan motivasi dalam belajar yaitu motivasi belajar akan memberikan semangat sehingga peserta didik akan mengetahui tujuan belajarnya, serta muncul jika peserta didik mempunyai kemauan belajar (8). "Guru adalah motivator dan menjadi contoh bagi siswa, apa yang dilakukan oleh guru akan ditiru oleh peserta didik" (9).

Motivasi adalah dasar bagi manusia dan kehendak perilaku, dan beberapa teori yang berpengaruh telah diajukan untuk menjelaskan mengapa individu memilih atau bertahan dalam suatu tindakan dibandingkan yang lain (10). Motivasi belajar memiliki fungsi beberapa fungsi yaitu mendorong, menggerakkan dan mengarahkan kegiatan peserta didik ke sisi yang lebih baik dalam belajar fisika sehingga mendapat hasil yang maksimal dalam pembelajaraan. Ketika proses pembelajaran guru tentunya mamberikan motivasi untuk peserta didik sehingga menumbuhkan semangat mereka. Namun penting bagi guru untuk mengetahui motivasi seperti apa yang harus diberikan untuk peserta didik. Dengan usaha yang seungguh-sungguh terutama didasari dengan motivasi, maka peserta didik yang belajar akan mampu memahami konsep suatu materi dengan baik.

Berdasarkan pertimbangan dan uraian di atas, peneliti melukan penelitian ini dengan tujuan untuk mengetahui hubungan antara motivasi belajar dengan pemahaman konsep peserta didik. Dari tujuan penelitian ini, peneliti berharap menemukan informasi seperti apa hubungan motivasi belajar dengan pemahaman konsep fisika peserta didik, serta seberapa besar hubungannya, sehingga dapat dijadikan pilihan bagi peneliti lainnya serta menjadi pengetahuan tambahan untuk guru saat melangsungkan pembelajaran pembelajaran. Dari penelitian ini, kedepannya untuk guru-guru saat memberikan pembelajaran agar memperhatikan dan memberikan motivasi belajar kepada peserta didik agar peserta didik menjadi bersemangat dalam belajar. Peserta didik dengan motivasi belajar yang baik, hasil belajar akan meningkat $(11,12)$. Hasil belajar dalam hal ini memiliki kaitan dengan 
pemahaman konsep, dimana pemahaman konsep merupakan bagian dari hasil belajar pada ranah kognitif. Selain itu dalam sebuah penelitian, dikatakan bahwa ada hubungan antara pemahaman konsep dengan hasil belajar (13).

\section{METODE PENELITIAN}

Penelitian ini menggunakan desain korelasional, yang berarti peneliti berniat untuk melihat ada atau tidaknya hubungan antara dua variabel, yakni motivasi belajar dengan pemahaman konsep fisika peserta didik. Penelitian ini menggunakan pendekatan kuantitatif sebab data yang diperoleh merupakan angka-angka hasil dari tes dan nontes yang diberikan ke peserta didik.

Penelitian ini dilaksanakan di MAN Baraka Enrekang pada bulan Februari 2017. Populasi penelitian ini adalah kelas X MIA yang terdiri dari 121 orang peserta didik. Dengan menggunakan sampling jenuh, maka diperoleh sampel adalah keseluruhan dari populasi. Sampling jenuh merupakan eknik pengambilan sampel apabila seluruh populasi dajadikan sebagai sampel (14).

Instrumen penelitian ini terdiri dari instrument yaitu instrument non-tes untuk mengumpulkan data motivasi belajar serta instrument tes untuk skor pemahaman konsep fisika. Intrumen non-tes menggunakan kuisioner dengan jumlah 37 pernyataan dengan 5 pilihan jawaban. Kemudian instrument tes menggunakan pilihan ganda dengan jumlah 26 soal dan 5 alternatif jawaban.

Korelasi produk momen merupakan teknik analisis data yang digunakan oleh peneliti untuk mengetahui hubungan kedua variabel, apakah ada hubungan atau tidak dan seperti apa hubungan kedua variabel tersebut. Berikut desain penelitian korelasi produk momen:

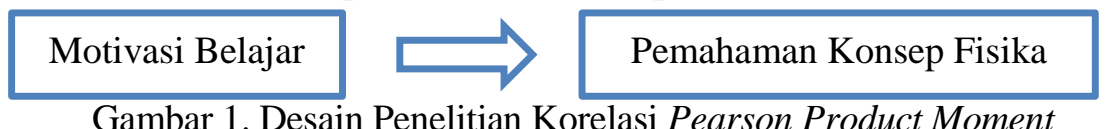

Gambar 1. Desain Penelitian Korelasi Pearson Product Moment

Sebelum melakukan analisis korelasi, peneliti melakukan uji prasyarat berupa uji normalitas dan uji linearitas. Jika syarat sudah terpenuhi, kemudian dilanjutkan ke uji hipotesis atau uji korelasi pearson. Berikut hipotesis dalam penelitian ini:

Ho : tidak ada hubungan antara motivasi belajar dengan pemahaman konsep fisika peserta didik MAN Baraka.

Ha : ada hubungan antara motivasi belajar dengan pemahaman konsep fisika peserta didik MAN Baraka.

\section{HASIL DAN PEMBAHASAN}

Setelah dilakukan penelitian, diperoleh data yang kemudian dianalasis sesuai dengan yang telah ditentukan sebelumnya.

\subsection{Motivasi Belajar}

Data motivasi belajar peserta didik setelah dilakukan pengumpulan data dari 121 peserta didik diperoleh skor motivasi belajar maksimal 175 dan skor minimal 106 dengan rata-rata skor 149. Selain itu diperleh juga tingkat motivasi belajar peserta didik yang dapat dilihat pada diagram berikut:

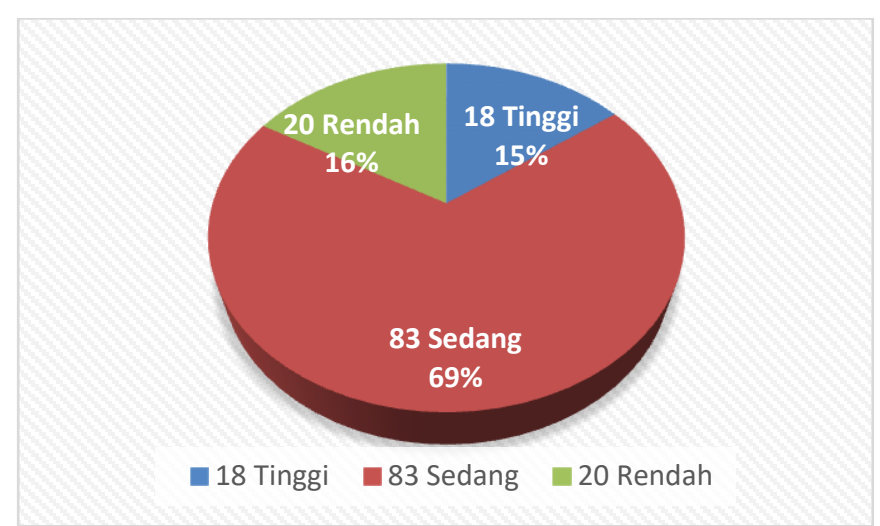

Gambar 1. Diagram tingkat motivasi belajar peserta didik

Dari diagram di atas, dapat dilihat bahwa motivasi belajar perserta didik kelas X MIA rata-rata 
berada pada tingkatan sedang dengan $69 \%$ atau sekitar 83 peserta didik dari 121 orang, dimana sisanya berada pada tingkatan rendah sebesar $16 \%$ atau sekitar 20 peserta didik dan $15 \%$ atau 18 peserta didik pada tingkatan tinggi.

Motivasi menempati posisi yang penting untuk meraih tujuan pembelajaran, oleh karenanya motivasi dari dalam diri maupun luar diri harus ada dalam diri peserta didik sehingga target pembelajaran yang telah disiapkan diawal bisa terlaksana secara maksimal (8). Dari gambar 2 bisa dilihat, sebenarnya motivasi belajar peserta didik sudah cukup baik sebab sebagian besar peserta didik sudah berada pada tingkatan motivasi yang baik dan hanya sebagian kecil yang dengan motivasi belajar rendah. Motivasi belajar sebagai salah satu unsur yang menentukan keberhasilan pembelajaran (15). Dalam pembelajaran, motivasi menjadi pemantik bagi peserta didik dalam menarik perhatian terhadap suatu materi. Peserta didik dengan motivasi yang tinggi akan memiliki rasa percaya diri serta keinginan yang besar untuk belajar, begitupun sebaliknya.

\subsection{Pemahaman Konsep Fisika}

Data pemahaman konsep fisika peserta didik setelah dilakukan tes dapat dilihat pada tabel 1 berikut:

Tabel 1. Deskripsi Data Pemahaman Konsep Fisika Peserta Didik

\begin{tabular}{ccccc}
\hline & $\begin{array}{c}\text { N } \\
\text { Statistik }\end{array}$ & $\begin{array}{c}\text { Skor } \\
\text { Minimum }\end{array}$ & $\begin{array}{c}\text { Skor } \\
\text { Maksimum }\end{array}$ & $\begin{array}{c}\text { Skor Rata- } \\
\text { rata }\end{array}$ \\
\hline Pemahaman Konsep & 121 & 9 & 23 & 16,38
\end{tabular}

Berdasarkan tabel 1 dapat dilihat bahwa dari total 26 soal pemahaman konsep fisika (skor penuh adalah 26), skor tertinggi yang mampu diperoleh peserta didik adalah 23 sedangkan skor terendah adalah 9., dengan rata-rata skor 16,38. Untuk melihat lebih jelas deskripsi dari pemahaman konsep fisika, bisa dilihat pada diagram berikut:

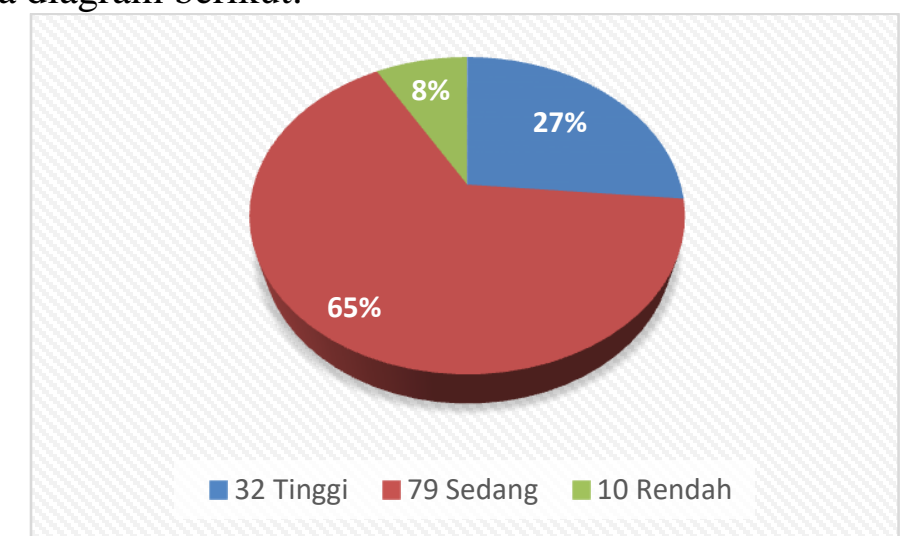

Gambar 2. Diagram tingkat pemahaman konsep fisika peserta didik

Diagram di atas menunjukan persentasi dari tingkat pemahaman konsep fisika peserta didik, yang mana dikketahui bahwa pemahaman konsep fisika peserta didik terletak pada tingkatan sedang. Bisa dilihat $65 \%$ atau 79 orang berada pada timgkatan sedang, sedangkan sisanya $27 \%$ atau 32 orang pada tingkatan tinggi, dan pada tingkatan rendah ada $8 \%$ atau 10 orang saja. Ini menunjukkan jika peserta didik kelas X MIA, sudah lumayan baik dalam memahami konsep-konsep fisika yang dipelajari di kelas. Pemahaman konsep sebagai salah satu indikator dalam proses pembelajaran sangat penting untuk perhatikan oleh guru-guru yang mengajar, terutama guru fisika. Peserta didik ketika dalam pembelajaran mampu memahami konsep dengan baik, akan mampu untuk meningkatkan hasil belajarnya (13).

\subsection{Hubungan Motivasi Belajar dengan Pemahaman Konsep Fisika Peserta Didik}

Untuk mengatahui hubungan antara motivasi belajar dengan pemahaman konsep fisika peserta didik, maka akan dilakukan dilakukan dengan menggunakan uji korelasi produk momen. Namun sebelumnya, ada syarat-syarat yang harus terpenuhi yakni data harus berdistribusi normal dan linear. Hasil uji normalitas data dapat dilihat pada tabel berikut: 
Tabel 2. Hasil Uji Normalitas

\begin{tabular}{llr}
\hline & & $\begin{array}{c}\text { Unstandardized } \\
\text { Residual }\end{array}$ \\
\hline$N$ & & 121 \\
\hline Normal Parameters & Mean & .0000000 \\
\cline { 2 - 3 } & Std. Deviation & 2.83533623 \\
\hline Most Extreme Differences & Absolute & .061 \\
\cline { 2 - 3 } & Positive & .061 \\
\cline { 2 - 3 } & Negative & -.054 \\
\hline Test Statistic & & .061 \\
\hline Asymp. Sig. (2-tailed) & & $.200^{\mathrm{c}, \mathrm{d}}$ \\
\hline
\end{tabular}

Berdasarkan hasil uji normalitas, diperoleh nilai siginifikansi 0,200>0,05. Sehingga dapat disimpulkan bahwa data yang digunakan berasaldari kelompok data yang berdistribusi normal. Sedangkan untuk hasil uji linearitas dapat dilihat pada tabel di bawah ini:

Tabel 3. Hasil Uji Linearitas Data

\begin{tabular}{|c|c|c|c|c|c|c|c|}
\hline & & & $\begin{array}{c}\text { Sum of } \\
\text { Squares }\end{array}$ & df & $\begin{array}{l}\text { Mean } \\
\text { Square }\end{array}$ & $\mathbf{F}$ & Sig. \\
\hline \multirow{5}{*}{$\begin{array}{l}\text { Pemahaman } \\
\text { Konsep * } \\
\text { Motivasi } \\
\text { Belajar }\end{array}$} & \multirow{3}{*}{$\begin{array}{l}\text { Between } \\
\text { Groups }\end{array}$} & (Combined) & 338.716 & 39 & 8.685 & 1.026 & .451 \\
\hline & & Linearity & 59.817 & 1 & 59.817 & 7.065 & .009 \\
\hline & & $\begin{array}{l}\text { Deviation from } \\
\text { Linearity }\end{array}$ & 278.900 & 38 & 7.339 & .867 & .682 \\
\hline & \multicolumn{2}{|c|}{ Within Groups } & 685.796 & 81 & 8.467 & & \\
\hline & \multicolumn{2}{|l|}{ Total } & 1024.512 & 120 & & & \\
\hline
\end{tabular}

Berdasarkan hasil uji linearitas, didapatkan nilai Sig. Deviation from Linearity 0,682 >0,05. Maka dapat dikatakan terdapat hubungan yang linear antara motivasi belajar dengan pemahamann konsep fisika peserta didik.

Setelah uji prasyarat terpenuhi, dimana data yang digunakan berasal dari kelompok yang berdistribusi normal dan kedua variabel terdapat hubungan yang linear, maka dapat dilakukan analisis lanjutan untuk menguji hipotesis penelitian. Analisis lanjutan ini menggunakan uji korelasi pearson (korelasi produk momen). Hal ini dilakukan sesuai dengan tujuan dari penelitian yaitu untuk hubungan dari variabel motivasi belajar dengan variabel pemahaman konsep fisika, serta hubungan seperti apa yang dimiliki keduanya. Pengujian ini dilakukan dengan bantuan dari software IMB SPSS Statistics 24. Hasil analisis dapa dilihat pada tabel berikut:

Tabel 4. Uji Hipotesis dengan Korelasi Paerson Produk Momen

\begin{tabular}{llr|r}
\hline & & \multicolumn{1}{c|}{$\begin{array}{c}\text { Motivasi } \\
\text { Belajar }\end{array}$} & \multicolumn{1}{c}{$\begin{array}{c}\text { Pemahaman } \\
\text { Konsep }\end{array}$} \\
\hline Motivasi Belajar & Pearson Correlation & 1 & $.242^{* *}$ \\
\cline { 2 - 4 } & Sig. (2-tailed) & 121 & .008 \\
\cline { 2 - 4 } & $\mathrm{N}$ & $.242^{* * *}$ & 121 \\
\hline Pemahaman Konsep & Pearson Correlation & .008 & 1 \\
\cline { 2 - 4 } & Sig. (2-tailed) & 121 & 121 \\
\cline { 2 - 4 } & $\mathrm{N}$ & 121 & \\
\hline
\end{tabular}

**. Correlation is significant at the 0.01 level (2-tailed).

Dari tabel 4, didapatkan nilai Sig. (2-tailed) $0,008<0,05$. Maka dapat dikatakan bahwa ada hubungan antara motivasi belajar dengan pemahaman konsep fisika peserta didik. Sedangkan derajat hubungan dapat antara motivasi belajar dengan pemahaman konsep fisika peserta didik berada pada tingkatan hubungan lemah (korelasi lemah). Pada tabel 4 diketahui nilai Pearson Correlation $=0,242$ yang berarti korelasi lemah. Hal ini berdasarkan pada pedoman berikut:

Tabel 5. Pedoman Interpretasi Koefisien Korelasi

\begin{tabular}{cc}
\hline Interval Korelasi & Tingkat Hubungan \\
\hline $0,00-0,19$ & Sangat Lemah \\
$0,20-0,39$ & Lemah
\end{tabular}




\begin{tabular}{cc}
\hline Interval Korelasi & Tingkat Hubungan \\
\hline $0,40-0,59$ & Sedang \\
$0,60-0,79$ & Kuat \\
$0,880-1,00$ & Sangat Kuat \\
\hline
\end{tabular}

Sumber: Riduwan dan Sunarto (16)

Hasil analisis ini juga menunjukkan arah hubungan antara variabel motivasi belajar dengan pemahaman konsep fisika peserta didik merupakan arah hubungan positif. Artinya setiap peningkatan skor dalam motivasi belajar, akan disertai juga dengan kenaikan skor pemahaman konsep fisika peserta didik walaupun tidak langsung terlihat. Ini dikaarenakan oleh korelasi keduanya berdasarkan hasil analisis berada pada pada tingkat hubungan yang lemah.

Hasil penelitian ini sejalan dengan penelitian yang dilakukan oleh Yusuf yang melakukan penelitian mengenai "Analisis Hubungan Motivasi Belajar Dengan Pemahaman Konsep Gerak Lurus Mahasiswa Pendidikan Fisika" yang menghasilkan kesimpulan bahwa motivasi belajar memiliki hubungan yang linear dengan pemahaman konsep serta berkorelasi positif dengan signifikansi (2-tailed) sebesar $0,001<0,05$ (6). Penelitian lainnya juga oleh Mutoharo menyimpukan hal serupa yakni kedua variabel berkorelasi positif, bahkan dalam penelitiannya, korelasi kedua variabel ini termasuk dalam kategori korelasi yang kuat, serta dalam penelitiannya pula mengatakan bahwa motivasi belajar memeliki kontribusi yang signifikan terhadap pemahaman konsep peserta didik $(17,18,19)$.

Berdasarkan uraian di atas, kita mengetahui bahwa motivasi belajar dan pemahaman konsep fisika berkorelasi positif. Sehingga hal ini perlu menjadi acuan bagi guru-guru maupun dosen serta para pendidik lainnya ketika sedang mengajar. Motivasi belajar bisa menjadi penguatan belajar saat peserta didik berhadapan dengan masalah yang menentukan pemecahan dan hanya dapat dipecahkan melalui bantuan dari hal-hal yang pernah dilalui (20). Meskipun dalam penelitian ini hanya ditemukan korelasi yang lemah, hal ini tidak menutup kemungkinan disebabkan oleh faktor yang mempengaruhi pemahaman konsep fisika peserta didik bukan hanya motivasi belajar saja, melainkan ada faktor lainnya. Faktor lainnya yang mempengaruhi pemahaman konsep selain motivasi adalah minat belajar peserta didik (21).

Terlepas dari faktor lainnya, Radosevich et al. dalam Slavin mengungkapkan bahwa peserta didik dengan motivasi tinggi saat belajar lebih mudah dan mampu merencanakan, melaksanankan pembelajaran dan mengingat pelajaran yang diperoleh (22). Berdasarkan hal tersebut, peneliti mengemukakan bahwa motivasi belajar merupakan salah satu potongan kecil yang tetapi berarti untuk peserta didik ketika pembelajaran. Oleh karena itu, pentingnya kesadaran dari pendidik mengenai motivasi belajar dan bagaimana cara pendidik dalam memberikan motivasi belajar bagi peserta didiknya agar peserta didik termotivasi dalam belajar dan mampu memahami pelajaran yang diberikan terutama konsep-konsep dari materi yang diajarkan, mengingat korelasi antara motivasi belajar dengan pemahaman kosep fisika ini berkorelasi positif.

\section{SIMPULAN DAN SARAN}

\subsection{Simpulan}

Simpulan dari penelitian ini diperoleh ada hubungan antara motivasi belajar dengan pemahaman konsep fisika peserta didik MAN Baraka.

4.2 Saran

Berdasarkan penelitian ini, disarankan untuk pendidik dalam lingkup manapun agar tidak lupa memperhatikan motivasi belajar peserta didik demi kelancaran proses pembelajaran. Selain itu, bagi peneliti yang memeliki penelitian terkait variabel penelitian ini agar sekiranya menyempurnakan hal-hal yang belum dapat dituangkan ke dalam tulisan ini.

\section{DAFTAR PUSTAKA}

1. Dimyati D, Mudjiono D. Belajar dan Pembelajaran. Jakarta: PT Rineka Cipta; 2013.

2. Murizal A. Pemahaman Konsep Matematis Dan Model Pembelajaran Quantum Teaching. $J$ 
Pendidik Mat. 2012;1(1).

3. Mauke M, Sadia W, Suastra W. Pengaruh Model Contextual Teaching and Learning Terhadap Pemahaman Konsep dan Kemampuan Pemecahan Masalah dalam Pembelajaran IPA-Fisika di MTs Negeri Negara. Vol. 3, Journal Program Pascasarjana Universitas Pendidikan Ganesha Program Studi IPA. 2013 Jul [cited 2020 Jul 2]. Available from: http://oldpasca.undiksha.ac.id/e-journal/index.php/jurnal_ipa/article/view/796

4. Masitoh, I. dan Prabawanto S. Peningkatan Pemahaman Konsep Matematika dan Kemampuan Berpikir Kritis Matematis Siswa Kelas V Sekolah Dasar Melalui Pembelajaran Eksploratif. EduHumaniora J Pendidik Dasar. 2015;7(2).

5. Pranata E. Implementasi Model Pembelajaran Group Investigation (GI) Berbantuan Alat Peraga Untuk Meningkatkan Kemampuan Pemahaman Konsep Matematika. J Pendidik Mat Indonesia. 2016;1(1):34-8.

6. Yusuf M, Hidayatullah MD, Tri I, Pamungkas, Faizah R. Analisis Hubungan Motivasi Belajar Dengan Pemahaman Konsep Gerak Lurus Mahasiswa Pendidikan Fisika. J Ris $\begin{array}{llll}\text { Pendidik Fis. 2017;2(2):49-55. Available } & \text { from: }\end{array}$ http://journal2.um.ac.id/index.php/jrpf/article/view/11221/5261

7. M. F, Nyeneng IDP, Maharta N. Pengaruh Motivasi Belajar dan Keterampilan Proses Sains Terhadap Pemahaman Konsep Fisika Siswa. Vol. 1, Jurnal Pembelajaran Fisika. 2013 Apr $\begin{array}{lllll}\text { [cited } 2020 & \text { Jul } & \text { Available }\end{array}$ http://jurnal.fkip.unila.ac.id/index.php/JPF/article/view/409

8. Emda A. Kedudukan Motivasi Belajar Siswa Dalam Pembelajaran. Lantanida J. 2018;5(2):172.

9. Annajmi. Peningkatan Kemampuan Pemahaman Konsep Matematika Siswa SMP Melalui Metode Penemuan Terbimbing Berbantuan Software Geogebra. J MES (Journal Math Educ Sci. 2016;2(1):1-10.

10. Hattie J, Hodis FA, Kang SHK. Theories of motivation: Integration and ways forward. Contemp Educ Psychol. 2020 May 20;101865.

11. Santoso B, Putri DH, Medriati R. Upaya Meningkatkan Motivasi Belajar dan Kemampuan Pemecahan Masalah Siswa Melalui Model Problem Based Learning Berbantu Alat Peraga Konsep Gerak Lurus. J Kumparan Fis. 2020 Apr 28;3(1):11-8.

12. Anas M, Aryani F. Motivasi Belajar Mahasiswa. Penelit Pendidik Insa. 2014;16(1):41-6.

13. Nur L, Siregar K, Pendahuluan A. Korelasi Pemahaman Konsep Aljabar dengan Hasil Belajar Matematika. J Pendidik Islam dan Teknol Pendidik. 2017;VII(1):22-33.

14. Sugiyono. Metode Penelitian Pendidikan Pendekatan Kuantitatif, Kualitatif, dan R\&D. Bandung: Alfabeta; 2014.

15. Sardiman. Interaksi dan Motivasi Belajar Mengajar. Jakarta: PT Raja Grafindo Persada; 2011.

16. Riduwan, Sunarto. Pengantar Statistika: Untuk Penelitian Pendidikan, Sosial, Ekonomi, Komunikasi dan Bisnis. Bandung: Alfabeta; 2011.

17. MUTOHARO ZR, SITI. Hubungan Motivasi Belajar Terhadap Pemahaman Konsep IPA Pada Siswa Kelas VIII SMP Negeri 21 Surabaya. Pensa E-Jurnal Pendidik Sains. 2015 [cited 2020 Jun 30];3(02). Available from: https://jurnalmahasiswa.unesa.ac.id/index.php/pensa/article/view/11505/10829

18. Astuti IAD. Upaya meningkatkan motivasi belajar dan pemahaman konsep IPA peserta didik dengan model pembelajaran problem posing. J Ris dan Kaji Pendidik Fis. 2016;3(2):39. 
19. Wahyuningsih D, Wahyuni S. Motivasi Belajar dan Pemahaman Konsep Fisika Siswa SMK dalam Pembelajaran Menggunakan Model Experiential Learning. J Pembelajaran Fis. 2014;

20. Hamzah B. Uno. Teori Motivasi dan Pengukurannya: Analisis di Bidang Pendidikan. Jakarta: Bumi Aksara; 2011.

21. Riwanto D, Azis A, Arafah K. Analisis Pemahaman Konsep Peserta Didik dalam Menyelesaikan Soal-Soal Fisika Kelas X MIA SMA Negeri 3 Soppeng. J Sains dan Pendidik Fis. 2019;15(2):23-31.

22. Slavin RE. Psikologi Pendidikan Teori dan Praktik. Terjemahan Marianto Samosir. Jakarta: PT Indeks; 2011. 